\title{
Cervical blood flow velocity values in patients with unilateral intracranial aneurysm: Preliminary results
}

\author{
Tek taraflı intrakranial anevrizmalı hastalarda servikal kan akış hızı değerleri: Ön \\ sonuçlar
}

Engin Tekin ${ }^{1}$, Murat Pehlivan ${ }^{2}$, Ömer Kitiş ${ }^{3}$

\section{Abstract}

Aim: Brain aneurysm is a balloon shaped dilatation of brain vessels as a result of attenuation of the vessel walls. The aim of this study was to evaluate the relationship between blood flow velocities in the right and left arterial vessels in an unruptured aneurysm and healthy group, and to investigate whether this analysis can help early diagnosis of aneurysm.

Methods: Four aneurysm patients (four female, mean age $57.25 \pm 0.75$ years) and four healthy subjects (two female, 2 male male, mean age $36.35 \pm 6.19$ years) were included in the study. Blood flow velocity values of right and left internal carotid arteries, vertebral artery and right and left internal jugular veins were obtained during a cardiac cycle with phase contrast technique. Spearman's correlation analysis was applied to flow velocity values. Statistically significant blood flow similarities between right and left brain were investigated. Results: In the aneurysm group, there was a significant difference between right and left cervical arterial blood flow velocity values $(\mathrm{p}=0.001)$. Spearman correlation coefficient values between right and left arterial blood flow velocity values and right and left side arteriovenous blood flow velocity values were lower in the aneurysm group compared to the control group however, there was no statistical significance ( $\mathrm{p} \geq 0.05$ for all).

Conclusion: The difference between the right and left arterial blood flow velocities obtained in the aneurysm group and the low correlation values may be useful in early diagnosis of aneurysm.

Key words: Cerebral aneurysm, Spearman's correlation analysis, blood flow velocity, phase contrast MR.

Öz

Amaç: Beyin anevrizması damar çeperlerindeki zayıflama sonucu beyin damarlarında oluşan balon şeklinde genişlemedir. Bu araştırmanın amacı, kanamasız anevrizmalı ve sağlıklı grupta sağ ve sol arteriyel damarlardak kan akış hızlarını değerlendirmek ve bu analizin anevrizma ön tanısına yardımcı olup olamayacağını araştırmaktır.

Yöntemler: Araştırmaya dört anevrizma hastası (dört kadın, ortalama yaş 57,25 $\pm 0,75$ ) ve dört sağlıklı denek (iki kadın, iki erkek, ortalama yaş $36,35 \pm 6,19$ ) dahil edildi. Sağ ve sol iç karotis arter, vertebral arter ve sağ ve sol iç jugular ven kan akış hızı değerleri faz kontrast tekniği ile bir kardiyak döngü boyunca elde edildi. Spearman'ın ilişki analizi akış hızı değerlerine uygulandı. Beyinin sağı ve solu arasındaki istatistiksel olarak anlamlı kan akış benzerlikleri araştırıldı.

Bulgular: Anevrizma grubunda, sağ ve sol taraf servikal arteriyel kan akış hızı değerleri arasında anlamlı fark bulundu ( $\mathrm{p}=0,001)$. Sağ ve sol arteriyel kan akış hızı değerleri arasındaki ve sağ ve sol taraf arteriyovenöz kan akış hızı değerleri arasındaki Spearman ilişki katsayı değerleri anevrizma grubunda kontrol grubuna göre düşüktü, ancak istatistiksel anlamll1ık yoktu (hepsi için $\mathrm{p} \geq 0,05$ ).

Sonuç: Bu ön araştırmanın sonuçları, anevrizma grubunda elde edilen sağ ve sol arteriyel kan akış hızları arasındaki belirgin farkın ve düşük ilişki değerlerinin anevrizma tanısında faydalı olabileceğini düşündürdü.

Anahtar kelimeler: Beyin anevrizması, Spearman ilişki analizi, kan akış hızı, faz kontrast MR.
${ }^{1}$ Usak University School of Health Sciences, Medical Imaging, Usak, Turkey.

${ }^{2}$ Ege University Faculty of Medicine, Dept of Biophysics, Izmir, Turkey.

${ }^{3}$ Ege University Faculty of Medicine, Dept of Radiodiagnostics, Izmir, Turkey.

Ethics Committee Approval: The study was approved by the local ethical authority. Etik Kurul Onayı: Çalışma lokal etik komite tarafından onaylanmıștır.

Conflict of Interest: No conflict of interest was declared by the authors.

Çıkar Çatışması: Yazarlar çıkar çatışması bildirmemişlerdir.

Financial Disclosure: The authors declared that this study has received no financial support.

Finansal Destek: Yazarlar bu çalışma için finansal destek almadıklarını beyan etmişlerdir.

Geliş Tarihi / Received: 07.08.2018

Kabul Tarihi / Accepted: 13.02.2019

Yayın Tarihi / Published: 15.03.2019

This study was presented at the $1^{\text {st }}$ International Health Sciences Congress, 02-05 May, 2018, Mehmet Akif University, Burdur, Istanbul.

Bu çalıșma, 02-05 Mayıs 2018'de düzenlenen Burdur Mehmet Akif Üniversitesi 1. Uluslararası Sağlık Bilimleri Kongresi'nde sunulmuştur.

Sorumlu yazar / Corresponding author:

Engin Tekin

Adres/Address: 1 Eylül Kampüsü, MA3 Blok,

Kat1, İzmir Yolu 8. Km. 64200, Uşak, Turkey e-posta: engin.tekin@usak.edu.tr Tel/Phone: (+90) 5053971636

Copyright $(\mathrm{C}$ ACEM 


\section{Introduction}

Intracranial aneurysms are balloon-like pathologic dilations of the cerebral blood vessel walls. An estimated 2\%-5\% of the general population is affected bye intracranial aneurysms. Rupture of intracranial aneurysms is an event associated with high mortality and disability rates [1]. Due to the high mortality rate predetermining of the probality of an aneurysm is very precious for public health.

Aneurysms frequently encountered unilaterally, and also 'Mirror-like' aneurysm, which are located bilaterally on corresponding arteries, has been reported to constitute less than 5 $\%$ of overall aneurysm $[2,3]$.

The flow dynamics of cerebral aneurysms have been studied in numerous experimental models and clinical studies to investigate the role of aneurysmal hemodynamics in their initiation, growth and rupture [4-6]. However, flow velocity changes of the vessels that supplying brain has never been used before for early diagnosis of aneurysm.

Besides it was reported that the velocity-time waveforms would be key to knowing the effect of aneurysm on flow. Just considering the geometric changes in the artery caused by an aneurysm would seem to suggest that there must be some disruption in flow [7]. So it is expected that the hemodynamic change that occurs with the formation of the aneurysm in intracranial arteries will also affect the hemodynamics of blood in the arteries supplying brain. It is suggested that there may be a difference in the flow velocity of right and left cervical arteries in aneurysm cases. This statistically correlation between blood flow velocity values of the right and the left side arteries may be important for suspicion of aneurysm. As far as we know, this hypothesis has not been found in the literature so far. Therefore, in this preliminary study, we evaluated the blood flow velocity of the right and the left carotid and the vertebral arteries and the internal jugular vein to examine the changes in blood flow velocity of the vessels supplying brain in cerebral aneurysm cases.

\section{Material and methods}

The research was approved by the local ethics comittee (Ege University Ethical Committe of Clinical Studies; 13-2.1/14) and the study protocol adhered to the tenets of the Declaration at Helsinki. Written consent could not be taken due to the retrospective design of the study.

Four aneurysm patients (four female, mean, $56.25 \pm$ 0.75 years) and four control subjects (two female, two male, mean, $36.5 \pm 6.2$ years) between the ages of 21 to 73 years were included in the study. All patients with unruptured-unilateral aneurysms were retrospectively selected. There was no history of subarachnoid hemorrhage and other neurological diseases. Aneurysms were at the level of the right middle cerebral artery, the left anterior cerebral artery, the right posterior communicating artery, the left posterior communicating artery and saccular type. Aneurysm diameters were between 3.5 and 8 $\mathrm{mm}$. Controls had no history of cerebral aneurysm, stroke and other cerebrovascular diseases.

All Magnetic resonance examinations were performed with 1.5 Tesla Magnetic Resonance (MR) unit (Siemens Symphony, Erlangen, Germany). The quantitative evaluation of arterial and venous blood velocities were performed with two dimensional (2D) phase contrast technique. Phase images were obtained by perpendicular to the foramen magnum on axial plane. For the internal carotid artery, $\mathrm{C} 1$ cervical segment was measured. For the vertebral artery, V2 vertebral segment was measured. The measurement parameters were as follows: TR, 33 ms; TE, $7 \mathrm{~ms}$; slice thickness, $5 \mathrm{~mm}$; Flip Angle, 15; matrix, $256 \times 256$; FOV, $160 \mathrm{~mm}$. The number of images varied depending on the heart rate. The total acquisition times ranged between $25 \mathrm{~min}$ and $30 \mathrm{~min}$ depending on the patient's individual heart rate (18-25 acquired cardiac phases). Cardiac gating was performed prospectively with electrocardiogram. Velocity encoding (Venc) was set at $100 \mathrm{~cm} / \mathrm{s}$ for arterial blood flow velocity and $20 \mathrm{~cm} / \mathrm{s}$ for internal jugular vein velocity.

The acquired phase images were transferred to ARGUS (ARGUS flow analysis tool, QoSient, LLC. New York, USA) post-processing program. Region of interest (ROI) was placed on each phase images (Figure 1), and, then, velocity-time curves of the right and the left internal carotid artery, the vertebral artery and the internal jugular vein were obtained by phase contrast technique throughout one cardiac cycle. Data were interpolated to the maximum number of points (cardiac phases) allowed per cardiac cycle $(n=32)$ to equal the number of data for arteriovenous analysis.

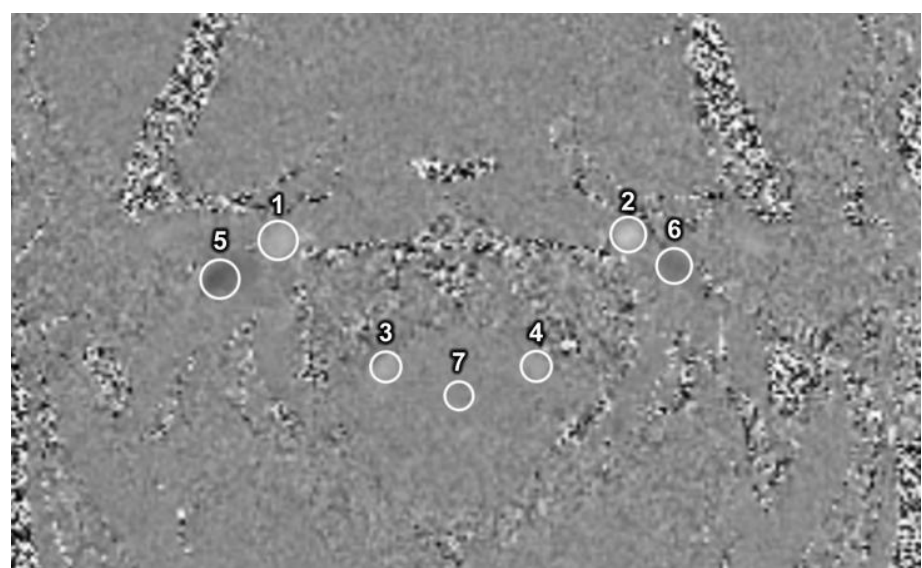

Figure 1. Region of interest (ROI) in phase images: 1, 2: Right and left internal carotid artery; 3, 4: Right and left vertebral artery; 5, 6: Right and left internal jugular vein; 7: Brain stem (using as a reference).

Spearman's correlation analysis was applied to flow velocity values (Table 1) including the correlation between blood flow velocity values of the right and the left internal carotid arteries in each subject (Correlation1-corr1), the correlation between total arterial blood flow velocities on the right and left side of brain (Correlation 2-corr2) and the correlation between right arteriovenous flow and left arteriovenous flow rates in each subject (Correlation 3-corr3).

Table 1. Descriptions of Spearman's correlation analysis groups.

Group Description

Correlation1 Between the right and the left internal carotid arteries.

Correlation2 Between sum of the internal carotid artery and the vertebral artery for the right side and sum of the internal carotid artery and the vertebral artery for the left side of brain.

Correlation3 Between arteriovenous flow at the right and left sides.

Arteriovenous flow was found by subtracting venous flow (the jugular vein) from total arterial flow (total carotid and vertebral artery flows) [8]. In the study, arteriovenous flow was calculated by subtracting the jugular vein blood flow velocity value from the sum of blood flow rates of the carotid and vertebral arteries separately for the right and left sides of brain.

\section{Statistical Analysis}

SPSS 11.0 statistical software program (SPSS Inc., Chicago, IL) was used for statistical tests. Mann-Whitney U test was used to determine whether there was a difference between the right and the left internal carotid, the vertebral artery and the 
internal jugular vein blood flow velocity values of each subject and if the Spearman's correlation coefficient values were significantly different between the aneurysm and the control group. $\mathrm{P}$ values less than or equal to 0.05 were considered as statistically significant.

\section{Results}

An example of right and left internal carotid and vertebral artery and internal jugular vein velocity-time curves obtained from the aneurysm and control group subjects are shown in Figures 2, 3 and 4. As the flow rate was measured over a cardiac cycle, the time axis in the graphs varied according to the heart rate.
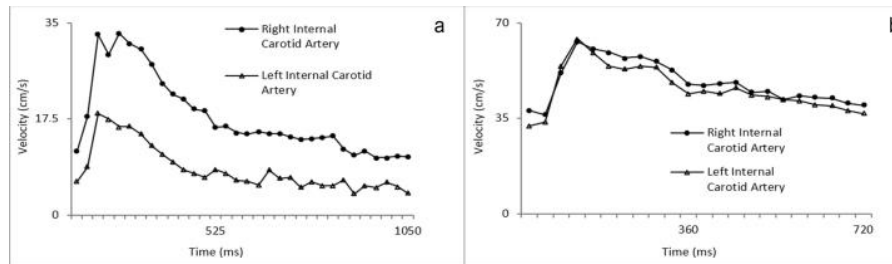

Figure 2. Velocity-time curves of internal carotid arteries. A) right and left internal carotid arteries of aneurysm subject B) right and left internal carotid arteries of healthy subject.
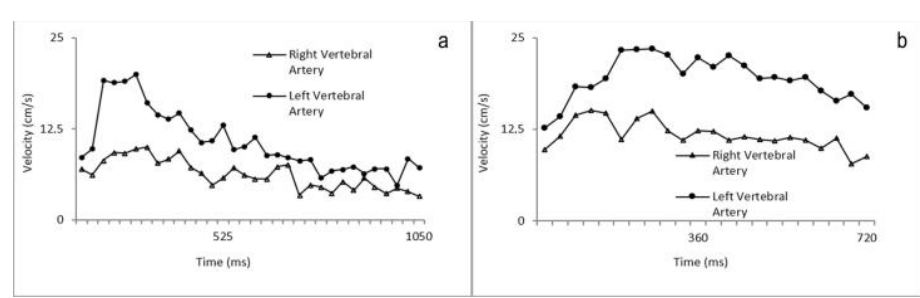

Figure 3. Velocity-time curves of vertebral arteries. A) right and left vertebral arteries of aneurysm subject B) right and left vertebral arteries of healthy subject.
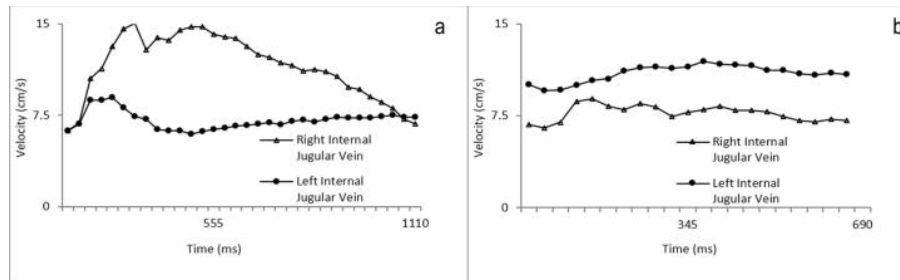

Figure 4. Velocity-time curves of internal jugular veins. A) right and left internal jugular veins of aneurysm subject B) right and left internal jugular veins of healthy subject.

The mean and peak velocities of the aneurysm group were smaller than control group in terms of flow velocity $(\mathrm{p}=0.001)$.The mean and peak blood velocities of arteries for right and left side of brain were significantly different in the aneurysm group as compared to control group (Table 2, 3). All blood velocity values are given as mean \pm std error.

Table 2. Values of the mean and peak velocities of the internal carotid artery for the aneurysm and control groups.

\begin{tabular}{lcccc} 
& \multicolumn{2}{c}{ Mean velocity $(\mathrm{cm} / \mathrm{s})^{¥}$} & \multicolumn{2}{c}{ Peak velocity $(\mathrm{cm} / \mathrm{s})^{¥}$} \\
\cline { 2 - 5 } Subject & Right & Left & Right & Left \\
\hline Aneurysm $(\mathrm{n}=2) *$ & $12.0 \pm 2.7$ & $23.6 \pm 4$ & $32.7 \pm 6.3$ & $46.6 \pm 4.1$ \\
Aneurysm $(\mathrm{n}=2) * *$ & $31.0 \pm 0.8$ & $17.3 \pm 0.7$ & $64.9 \pm 5.5$ & $50.3 \pm 4.5$ \\
Control $(\mathrm{n}=4)$ & $33.3 \pm 3.3$ & $33.4 \pm 2.5$ & $58.7 \pm 5.0$ & $61.7 \pm 4.4$ \\
\hline
\end{tabular}

*Aneurysm on the right side. ** Aneurysm on the left side.

${ }^{¥}$ :mean \pm standart deviation
Table 3. Values of the mean and peak velocities of the vertebral artery for the aneurysm and control groups.

\begin{tabular}{lcccc} 
& \multicolumn{2}{c}{ Mean velocity $(\mathrm{cm} / \mathrm{s})^{*}$} & \multicolumn{2}{c}{ Peak velocity $(\mathrm{cm} / \mathrm{s})^{*}$} \\
\cline { 2 - 5 } Subject & Right & Left & Right & Left \\
\hline Aneurysm $(\mathrm{n}=2) *$ & $4.4 \pm 1.0$ & $8.8 \pm 1.0$ & $25.4 \pm 8.5$ & $29.7 \pm 4.6$ \\
Aneurysm $(\mathrm{n}=2) * *$ & $6 \pm 1.6$ & $12.9 \pm 1.8$ & $12.4 \pm 3.9$ & $29.7 \pm 1.0$ \\
Control $(\mathrm{n}=4)$ & $12.7 \pm 0.6$ & $14.0 \pm 0.5$ & $23.2 \pm 0.5$ & $26.4 \pm 0.9$ \\
\hline *Aneurysm on the right side. ** Aneurysm on the left side.
\end{tabular}

*Aneurysm on the right side. ** Aneurysm on the left side.

: mean \pm error

There was no significant difference with regard to the mean and peak blood velocities of the jugular vein for the right and the left side of brain in two groups $(\mathrm{p}=0.196)$ (Table 4).

Table 4. Values of the mean and peak velocities of the jugular vein for the aneurysm and control groups.

\begin{tabular}{ccccc} 
& \multicolumn{2}{c}{ Aneurysm group $(\mathrm{n}=4)$} & \multicolumn{2}{c}{ Control Group $(\mathrm{n}=4)$} \\
\cline { 2 - 5 } Veins & $\begin{array}{c}\text { Mean } \\
\text { Velocity } \\
(\mathrm{cm} / \mathrm{s})^{\sharp}\end{array}$ & $\begin{array}{c}\text { Peak } \\
\text { Velocity } \\
(\mathrm{cm} / \mathrm{s})^{¥}\end{array}$ & $\begin{array}{c}\text { Mean } \\
\text { Velocity } \\
(\mathrm{cm} / \mathrm{s})\end{array}$ & $\begin{array}{c}\text { Peak } \\
\text { Velocity } \\
(\mathrm{cm} / \mathrm{s})^{¥}\end{array}$ \\
\hline $\begin{array}{c}\text { Right internal } \\
\text { jugular }\end{array}$ & $8.9 \pm 0.9$ & $16.4 \pm 1$ & $8.8 \pm 1.4$ & $19.3 \pm 0.1$ \\
$\begin{array}{c}\text { Left internal } \\
\text { jugular }\end{array}$ & $8.1 \pm 0.3$ & $14.4 \pm 0.8$ & $7.6 \pm 1.2$ & $17 \pm 0.5$ \\
\hline
\end{tabular}

${ }^{*}:$ mean \pm error.

Spearman's correlation coefficient values were lower in the aneurysm group compared to the control group for Corr1, Corr2 and Corr3 analysis, but there was no statistical significance (Table 5) $(\mathrm{p}=0.265)$.

Table 5. Spearman's correlation values of the aneurysm and control groups.

\begin{tabular}{lllccc} 
Age & Gender & Group & Correlation1 & Correlation2 & Correlation3 \\
\hline 57 & Female & Aneurysm & 0.768 & 0.787 & 0.559 \\
55 & Female & Aneurysm & 0.856 & 0.775 & 0.774 \\
58 & Female & Aneurysm & 0.728 & 0.746 & 0.712 \\
55 & Female & Aneurysm & 0.493 & 0.433 & $* 0.359$ \\
21 & Male & Control & 0.949 & 0.891 & 0.982 \\
21 & Male & Control & 0.980 & 0.982 & 0.978 \\
73 & Female & Control & 0.967 & 0.988 & $* 0.880$ \\
31 & Female & Control & 0.944 & 0.940 & 0.920 \\
\hline
\end{tabular}

*There was aliasing in the right and the left jugular veins.

For each correlation analysis, the mean values of correlation analysis in aneurysm and control group are listed in Table 6.

Table 6. Correlation values of the aneurysm and control groups.

\begin{tabular}{lccc} 
Group & Correlation $^{¥}$ & Correlation $^{¥}$ & Correlation $^{\ddagger}$ \\
\hline Aneurysm & $0.7113 \pm 0.0387$ & $0.6852 \pm 0.0422$ & $0.6010 \pm 0.0462$ \\
Control & $0.9600 \pm 0.0041$ & $0.9502 \pm 0.0112$ & $0.9400 \pm 0.0122$ \\
\hline :mean \pm error. & & &
\end{tabular}

\section{Discussion}

We found a difference between the right and left mean and peak blood velocity of the carotid and the vertebral arteries in aneurysm group. This result suggests that there is an asymmetry between the right and the left side of brain in the aneurysm group. Similarly, there are studies reporting that there is asymmetric blood flow in aneurysm cases. In patients with aneurysm in the basilar artery, the mean value of the right vertebral artery was $2.1 \mathrm{ml} / \mathrm{s}$ and the mean value of the left vertebral artery was $0.7 \mathrm{ml} / \mathrm{s}$. [9]. In another study, a flow rate of $54 \mathrm{ml} / \mathrm{min}$ on the right side and $93 \mathrm{ml} / \mathrm{min}$ on the left side of the patient with $2.5 \mathrm{~mm}$ aneurysm in the right anterior communicating artery was reported [10].

In addition, a study in the literature reported that the relationship between cerebral aneurysm size and risk of rupture was well documented but the effect of aneurysms on distal intracranial hemodynamics was not known [11]. The aneurysm 
cases (unruptured and unilateral) included in our study were similar to this study in the literature. Aneurysms in the carotid segments and they found that mean pulsatility index in the ipsilateral ICA was 0.38 and mean pulsatility index in contralateral ICA was 0.35 . Although aneurysms occured in the carotid artery, they could not find any difference between right and left carotid flow. However, this result was not similar to our results. We have found a significant asymmetry between the ipsilateral and contralateral sides in aneurysm group regard hemodynamic carotid flow. As far as we know, a study that evaluating preliminary diagnosis of intracranial aneurysms by using the blood flow dynamics of the arteries supplying the brain has not been found in the literature so far.

Besides this blood flow velocities in ipsilateral (on the obstructed side) internal carotid artery were lower compared with the contralateral (on the unobstructed side). This may be due to autoregulation. Blood flow velocities of ipsilateral vertebral artery were lower in comparison to contralateral in two patients, the other two patients had the opposite. It is thought that the reason for not getting meaningful difference is due to the vascular structures. It should be also investigated that in which side of brain (the aneurysm side or contralateral) the cervical artery velocities will be higher. Morover, more study on aneurysm cases is needed to understand if an asymmetry occurs because of an aneurysm formation or if an aneurysm cause an asymmetry.

An asymmetry between the right and left jugular vein blood flow velocities could not be obtained. In aneurysm groups, it should be investigated in more cases whether there is a blood flow asymmetry for jugular vein.

Corr 1 and corr2 analysis values were lower in the aneurysm group compared to the control group. These results show that aneurysm impairs blood flow dynamics in one side of brain. In the aneurysm group, low correlation values also suggest that there is an asymmetry between the right and the left side of brain in terms of total arterial blood flow velocity. It is thought that the cranial cerebral aneurysm has caused velocity change in the veins supplying the brain unilaterally and this change is compensated by the arterial elasticity.

It was reported that the net arterial flow into the skull over an average cardiac cycle must be equal the net outflow of venous blood plus possible net outflow of CSF through the Foramen Magnum and this is affected by the intracranial compliance and pressure [12]. So impact of aneurysm formation on the compliance was investigated in Corr3 analysis. The low Corr3 values found in the aneurysm group due to arteriovenous flow difference between the right and left sides. Compliance in the cervical veins has changed by the effect of autoregulation.

Skull is a rigid body that has apertures with vessels and Foramen Magnum. Any difference in compliance caused by pulsatile blood pressure may have revealed some delay in any fluid flow rate if there was an existing aneurysm. For this reason, Corr3 values may be a measure to show this flow rate delay as asymmetry. Further study with a large number of cases is needed to test this hypothesis.

There was no significant difference between right and left arterial blood flow velocities in the control group. The correlation coefficients were also higher in control group as compared to aneurysm group. These values indicate that there is no asymmetry between the right and left of brain. This result is also consistent with the literature. Since the aneurysm group consists of older subjects compared to the control group in this research, it may be thought that asymmetry have occurred because of age. Although there was a decrease in blood flow with age, no flow difference between right and left arteries supplying the brain was reported. [13-15].
Other conditions and diseases that may cause asymmetry should also be examined. This hemodynamic difference between the right and left sides and asymmetry may also be caused by other conditions and diseases such as stenosis and stroke. In the literature, increased blood flow velocity on the ipsilateral side was reported for carotid artery stenosis [16]. However, if an asymmetry in the cervical arteries is proved in aneurysms cases, an awareness will be created in clinicians for diagnosis of aneurysm.

Obtaining carotid and vertebral arteries blood flow values with doppler ultrasound are more practical than phase contrast MR technique. To take the advantage of doppler ultrasound, we propose to use ultrasound as a initial method for fast screening of aneurysm, as we have found correlation values of carotid artery flow (Corr1) smaller in aneurysm group in our study. If any suspicious flow velocities were found, then we propose to use phase contrast MR to get the detailed information for early diagnosis.

This study contains some limitations. Firstly, a small number of aneurysm patients cannot statistically indicate a powerful conclusion. The reason small number of patients is that data acquisition time is very long. In addition, the MR technique is sensitive to movement and heart beat.

The second limitation of the study is that a low Velocity Encoding (Venc) value was prefered while jugular vein blood flow velocity was being measured. As a result, Aliasing was observed. Venc value is an important measure to be set during phase contrast technique in MRI. If this value is set lower than the actual flow rate, aliasing occurs and unaccurate flow rate can be obtained. Higher Venc value should be selected in future studies.

In addition, further study is necessary to improve accuracy of cine MR imaging and to confirm its accuracy with that obtained by doppler ultrasound.

The use of a unilateral aneurysm group is a limitation in the study. It will not be possible to determine the velocity difference and the correlation between right and left sides in the bilateral aneurysm cases on the two sides of brain. To determine the the usefullness or accuracy of correlation analysis in bilateral aneurysms, unruptured bilateral aneurysm groups should be studied in comparison to control groups.

Vasculitis, stenosis and atherosclerosis were not seen in the image sections. In the origin of the vessels whose blood flow velocities were measured, any vascular disease that could lead to asymmetric blood flow have not been detected. However, the origin of the common carotid artery (CCA) could not be evaluated because it was not in the MRI image area. Another limitation of this study is that we don't know whether the asymmetric blood flow derived from a CCA-induced factor (but it is known that aneurysm patients do not have a history of cardiovascular disease).

As a result, in this preliminary study, asymmetry between the arteries supplying the right and left brain and low correlation coefficients were found in the aneurysm group. The use of this asymmetric flow in clinical routine practice may be important for early diagnosis of aneurysm. Therefore, more further studies should be performed in larger groups by using the doppler ultrasonography method.

\section{References}

1. Doddasomayajula R, Chung B, Hamzei-Sichani F, Putman CM, Cebra JR. Differences in Hemodynamics and Rupture Rate of Aneurysms at the Bifurcation of the Basilar and Internal Carotid Arteries. AJNR Am J Neuroradiol. 2017;38:570-6. 
2. Zhao L, Zhang L, Zhang X, Li Z, Tian L, Wang Y-XJ. An Analysis of 1256 Cases of Sporadic Ruptured Cerebral Aneurysm in a Single Chinese Institution. PLoS One. 2014;19:e85668.

3. Wang R, Zhang D, Zhao J, Wang S, Zhao Y, Niu H. A comparative study of 43 patients with mirror-like intracranial aneurysms: risk factors, treatment, and prognosis. Neuropsychiatr Dis Treat. 2014;10:2231-7.

4. Hu P, Qian Y, Lee CJ, Zhang HQ, Ling F. The energy loss may predict rupture risks of anterior communicating aneurysms: a preliminary result. Int J Clin Exp Med. 2015;8:4128-33.

5. Berg P, Beuing O. Multiple intracranial aneurysms: a direct hemodynamic comparison between ruptured and unruptured vessel malformations. Int J Comput Assist Radiol Surg. 2018;13:83-93.

6. Liu J, Fan J, Xiang J, Zhang Y, Yang X. Hemodynamic characteristics of large unruptured internal carotid artery aneurysms prior to rupture: a case control study. J Neurointerv Surg. 2016;8:367-72.

7. Gwilliam MN, Hoggard N, Capener D, Singh P, Marzo A, Verma PK et al. MR derived volumetric flow rate waveforms at locations within the common carotid, internal carotid, and basilar arteries. J Cereb Blood Flow Metab. 2009;29:1975-82.

8. El Sankari S G-JC, Fichten A, Godefroy O, Serot JM, Deramond H, Meyer ME, et al. Cerebrospinal fluid and blood flow in mild cognitive impairment and Alzheimer's disease: a differential diagnosis from idiopathic normal pressure hydrocephalus. Fluids Barriers CNS. 2011;8:12.

9. Boussel L, Rayz V, Martin A, Acevedo-Bolton G, Lawton MT, Higashida $\mathrm{R}$ et al. Phase-Contrast Magnetic Resonance Imaging Measurements in Intracranial Aneurysms In Vivo of Flow Patterns, Velocity Fields, and Wall Shear Stress: Comparison with Computational Fluid Dynamics. Magn Reson Med. 2009;61:409-17.

10. Karmonik C, Yen C, Grossman RG, Klucznik R, Benndorf G. Intraaneurysmal flow patterns and wall shear stresses calculated with computational flow dynamics in an anterior communicating artery aneurysm depend on knowledge of patient-specific inflow rates. Acta Neurochir (Wien). 2009;151:479-85.

11. Hussein AE, Brunozzi D, Shakur SF, Ismail R, Charbel FT, Alaraj A. Cerebral Aneurysm Size and Distal Intracranial Hemodynamics: An Assessment of Flow and Pulsatility Index Using Quantitative Magnetic Resonance Angiography. Neurosurgery. 2018;83:660-5.

12. Alperin N, Vikingstad EM, GomezAnson B, Levin DN. Hemodynamically independent analysis of cerebrospinal fluid and brain motion observed with dynamic phase contrast MRI. Magn Reson Med. 1996;35:741-54.

13. Filatova OV, Sidorenko AA, Skorobogatov YY. Age and Sex Dependence of Hemodynamic Parameters of Human Internal Carotid Arteries. Hum Physiol. 2014;40:554-62.

14. Salk İ, Yıldız G, Eğilmez H, Atalar MH, Candan F, Cetin A. Carotid artery Doppler ultrasonography in patients with chronic kidney disease. Med Sci Monit. 2014;20:11-7.

15. Al-Eqabi DAM, Al-Sia1dy WF, Al-Sabbagh AAJ, Al-Kırwi IN. Internal Carotid Peak-Systolic and End-Diastolic Velocities are the Sensitive Parameters in Predicting Conditions in Type 2 Diabetes. J Biomed Bioeng. 2013;4:90-2.

16. Hope TA, Hope MD, Purell DD, von Morze C, Vigneron DB, Alley MT et al. Evaluation of intracranial stenoses and aneurysms with accelerated 4D flow. Magn Reson Imaging. 2010;28:41-6. 